\title{
Cost-effectiveness of digital therapeutics for essential hypertension
}

Akihiro Nomura ${ }^{1-2^{*}}$, Tomoyuki Tanigawa ${ }^{3}$, Kazuomi Kario ${ }^{4}$, Ataru Igarashi ${ }^{5-6^{*}}$

${ }^{1}$ Innovative Clinical Research Center, Kanazawa University, Kanazawa, Japan

${ }^{2}$ Department of Biomedical Informatics, CureApp Institute, Karuizawa, Japan

${ }^{3}$ CureApp, Inc., Tokyo, Japan

${ }^{4}$ Division of Cardiovascular Medicine, Department of Medicine, School of Medicine, Jichi

Medical University, Tochigi, Japan

${ }^{5}$ Unit of Public Health and Preventive Medicine, Yokohama City University School of Medicine, Yokohama, Japan

${ }^{6}$ Health Economics \& Outcomes Research, Graduate School of Pharmaceutical Sciences, Faculty of Pharmaceutical Sciences, The University of Tokyo, Tokyo, Japan

* These authors contributed equally.

\section{Corresponding author:}

Ataru Igarashi, $\mathrm{PhD}$

Associate Professor

Unit of Public health and Preventive Medicine

Yokohama City University School of Medicine, Yokohama, Japan

E-mail: atarui1@mac.com 
medRxiv preprint doi: https://doi.org/10.1101/2022.03.02.22271583; this version posted March 4, 2022. The copyright holder for this preprint

(which was not certified by peer review) is the author/funder, who has granted medRxiv a license to display the preprint in perpetuity. It is made available under a CC-BY 4.0 International license .

\begin{abstract}
Background: Hypertension increases the risk of cardiovascular and other diseases. Lifestyle modification is a significant component of nonpharmacological treatments for hypertension. We previously reported the clinical efficacy of digital therapeutics (DTx) in the HERB-DH1 pivotal trial. However, there is still a lack of cost-effectiveness assessments evaluating the impact of prescription DTx. This study aimed to analyze the cost-effectiveness of using prescription DTx in treating hypertension.
\end{abstract}

Methods: We developed a monthly cycle Markov model and conducted Monte Carlo simulations using the HERB-DH1 trial data to investigate quality-adjusted life-years (QALYs) and the cost of DTx for hypertension plus guideline-based lifestyle modification consultation treatment as usual (TAU), comparing DTx+TAU and TAU-only groups with a lifetime horizon. The model inputs were obtained from published academic papers, publicly available data, and expert assumptions. The incremental cost-effectiveness ratio (ICER) per QALY was used as the benchmark for cost-effectiveness. We performed probabilistic sensitivity analyses (PSAs) using the Monte Carlo simulation with 2 million sets.

Results: The DTx+TAU strategy produced 18.778 QALY and was associated with $¥ 3,924,075$ $(\$ 34,122)$ expected costs, compared with 18.686 QALY and $¥ 3,813,358(\$ 33,160)$ generated by the TAU-only strategy over a lifetime horizon, resulting in an ICER of $¥ 1,199,880$ $(\$ 10,434) / \mathrm{Q} A L Y$ gained for DTx+TAU. The monthly cost and attrition rate of DTx for hypertension have a significant impact on ICERs. In the PSA, the probability of the DTx arm being a cost-effective option was $87.8 \%$ at a threshold value of $¥ 5$ million $(\$ 43,478) / \mathrm{QALY}$ gained.

Conclusions: The DTx+TAU strategy was more cost-effective than the TAU-only strategy. 
medRxiv preprint doi: https://doi.org/10.1101/2022.03.02.22271583; this version posted March 4, 2022. The copyright holder for this preprint

(which was not certified by peer review) is the author/funder, who has granted medRxiv a license to display the preprint in perpetuity. It is made available under a CC-BY 4.0 International license .

\section{Introduction}

Hypertension or elevated blood pressure (BP) is a serious health condition that significantly increases cardiovascular diseases (CVD), heart failure (HF), atrial fibrillation (AFib), renal dysfunction, and other disorders. ${ }^{1}$ Hypertension affects 1.28 billion people and is a leading modifiable risk factor attributing mortality worldwide. ${ }^{1,2}$ In Japan, there were more than 43 million patients with hypertension, having one of the highest prevalence among the Organization for Economic Co-operation and Development countries. ${ }^{3}$ Hypertension is attributed to cerebral and cardiovascular deaths, accounting for 50\% of all CVD deaths, $59 \%$ of coronary artery disease (CAD) deaths, and $52 \%$ of stroke deaths. ${ }^{4}$ Also, the total medical cost of these CVDs has reached nearly $\$ 100$ billion in Japan. ${ }^{5}$ Therefore, managing hypertension is one of the most critical issues for preventing CVDs and reducing medical costs in Japan. For this purpose, Health Japan 21 (the second edition) aims to reduce the average systolic $\mathrm{BP}(\mathrm{SBP})$ of the Japanese population by $4 \mathrm{mmHg}$ within 10 years by raising awareness and promoting lifestyle modification by a healthy diet, more physical activity, and reducing alcohol consumption at the national level. ${ }^{6}$

Lifestyle modification is a major component of non-pharmacological treatment for hypertension, which is as essential as antihypertensive pharmacological treatment. ${ }^{7}$ In principle, hypertensive patients at low risk for CVD should modify their lifestyle first, and antihypertensive drug therapy is initiated at an appropriate time according to the patients' future CVD risks. Lifestyle modification plays a vital role in lowering blood pressure because of its antihypertensive and synergistic effects along with antihypertensive drugs. ${ }^{8,9}$ However, the physician's limited outpatient time is insufficient to provide guideline-based hypertension management, including lifestyle modification suited for each patient's diverse lifestyle. ${ }^{10}$ As a result, lifestyle modification has not achieved its full effect in reducing BP. 
medRxiv preprint doi: https://doi.org/10.1101/2022.03.02.22271583; this version posted March 4, 2022. The copyright holder for this preprint

(which was not certified by peer review) is the author/funder, who has granted medRxiv a license to display the preprint in perpetuity. It is made available under a CC-BY 4.0 International license .

To maximize the potential treatment effect of lifestyle modification for hypertension, we developed a prescription digital therapeutics (DTx) for hypertension, the HERB system. ${ }^{11}$ The HERB system consists of a HERB Mobile smartphone app for patients and a web-based patient management software for primary doctors. ${ }^{11}$ We previously reported the HERB-DH1 phase III randomized controlled trial (RCT) results of the DTx for essential hypertension. In this trial, we randomly assigned 390 essential hypertension patients aged $\leq 65$ years who were not taking antihypertensive medication to the DTx intervention group or the control group. The results showed that the primary outcome of the 24-h SBP was significantly lower in the DTx intervention group than that in the control group. ${ }^{12}$

Although the HERB-DH1 trial demonstrated the clinical efficacy of DTx, there is still a lack of cost-effectiveness assessments evaluating the impact of the prescription DTx for hypertension on healthcare costs along with clinical efficacy. The cost-effectiveness of DTx for opioid use disorder or that for low back pain were recently evaluated using the RCT results. ${ }^{13-15}$ However, there is no study assessing the cost-effectiveness of prescription DTx for hypertension using the RCT data. Exploring the appropriate DTx pricing determined by costeffectiveness analysis is crucial in countries including Japan, whose DTx costs could be reimbursed by public health insurance.

Here, we aimed to analyze the cost-effectiveness of using prescription DTx in treating hypertension using the HERB-DH1 phase III RCT results. 
medRxiv preprint doi: https://doi.org/10.1101/2022.03.02.22271583; this version posted March 4, 2022. The copyright holder for this preprint (which was not certified by peer review) is the author/funder, who has granted medRxiv a license to display the preprint in perpetuity. It is made available under a CC-BY 4.0 International license .

\section{Methods}

We developed an economic model to assess the cost and effectiveness of DTx for essential hypertension. The model investigated quality-adjusted life-years (QALYs) and the cost of DTx for hypertension plus guideline-based lifestyle modification consultation treatment as usual (TAU) (DTx+TAU) vs. TAU only with a lifetime horizon and a 1-month cycle length. We constructed the model from the perspective of a public health care payer. We compared the cost-effectiveness of DTx+TAU with TAU alone for the treatment of CAD, stroke, HF, and AFib. We used the parameters of the HERB-DH1 phase III clinical trial ${ }^{12}$ as inputs. The HERBDH1 trial is an open-label RCT of HERB prescription DTx in 390 patients with essential hypertension. At 12 weeks, DTx+TAU intervention group exhibited a significant reduction of SBP compared with the TAU-only control group $(-10.6 \mathrm{mmHg}$ in DTx+TAU group vs -6.2 $\mathrm{mmHg}$ in the TAU-only control group by a home BP measurement). The present study evaluated outcomes as incremental cost-effectiveness ratio (ICER) per QALY gained. The model inputs were obtained from published academic papers, publicly available data, and expert assumptions. We conducted the analyses according to the Consolidated Health Economic Evaluation Reporting Standards (CHEERS) statement and the Ethics Guidelines for Medical and Biological Research Involving Human Subjects in Japan. The authors have the right to publish, regardless of the outcome. The Institutional Review Board approved the study protocol at Kanazawa University, Japan.

\section{Model structure and clinical pathway}

We developed a monthly cycle Markov model and conducted Monte Carlo simulations to estimate the efficacy of DTx+TAU (Figure 1). A Monte Carlo simulation, with $1,000,000$ iterations, was performed to reflect the variation in patient characteristics, such as age and treatment effects, mainly derived from those of enrollees for the clinical trial. The model 
medRxiv preprint doi: https://doi.org/10.1101/2022.03.02.22271583; this version posted March 4, 2022. The copyright holder for this preprint

(which was not certified by peer review) is the author/funder, who has granted medRxiv a license to display the preprint in perpetuity. It is made available under a CC-BY 4.0 International license .

consisted of patients who received DTx+TAU and those who received TAU only. We modelled three different health statuses as follows: "stay" (healthy without any acute complications), “acute complications " (suffering any acute complications regarding hypertension), and "death." Acute complications included CAD, stroke, HF, and AFib. We also considered natural deaths in the model. Hypertensive patients who avoid natural death can stay in the same acute complication-free status "stay" or experience acute complications of CAD, stroke, HF, or AFib. In this model, a patient with one of the acute complications must maintain the "acute complication" status or die directly from the complication for 12 months, then automatically recover and switch from the "acute complication" status to the "stay" status with a postcomplication (chronic) tag [return to the "stay" status but had slightly higher mortality rates than natural deaths in patients after having either of CAD, stroke, and HF]. We did not consider a patient with more than one complication within 12 months of the latest occurrence of acute complications.

\section{Time horizon}

We set lifetime years (50 years) as the time horizon for our study. We also conducted scenario analyses to slide the time horizon to 20,30 , and 40 years.

\section{Model population and intervention}

The study population was derived from the HERB-DH1 trial. They were grade I or II hypertensive patients without antihypertensive drug treatment, with a mean age of 52 years, $20 \%$ were female, $16 \%$ were current smokers, and the proportion of dyslipidemia and diabetes was $50 \%$ and $7 \%$, respectively. The average SBPs was $145 \mathrm{mmHg}$ in the $24-\mathrm{h} \mathrm{SBP}$ by ambulatory BP monitoring and $148 \mathrm{mmHg}$ in the morning home SBP by home BP monitoring. This model used log-normalized baseline home SBP distribution from HERB-DH1 trial data 
medRxiv preprint doi: https://doi.org/10.1101/2022.03.02.22271583; this version posted March 4, 2022. The copyright holder for this preprint (which was not certified by peer review) is the author/funder, who has granted medRxiv a license to display the preprint in perpetuity. It is made available under a CC-BY 4.0 International license .

(Table 1). Additionally, we modelled annual SBP increase in both groups by $0.5 \mathrm{mmHg}$ from the national survey. ${ }^{7}$

The DTx+TAU group received the prescription DTx, HERB Mobile system, and lifestyle modifications to manage hypertension recommended by the Japanese Society of Hypertension (JSH) guidelines. ${ }^{7}$ The HERB Mobile system include the HERB Mobile smartphone app and a web-based management application for healthcare providers. The smartphone app retrieves each patient's baseline input data, and daily home BP measurements transfer the data to the cloud server and assess them to plan a personalized lifestyle modification program to lower their BP. In addition, primary physicians can simultaneously browse their patients' data such as BP measurements, daily activities, or progress on the proposed program using a web-based application. ${ }^{11,} 12$ The TAU-only group also promoted lifestyle modifications for hypertension based on the JSH guidelines by their primary physicians or themselves. We assume that the hypertensive patients in the DTx+TAU group have an average home SBP reduction of $10.6 \mathrm{mmHg}$, while those in the TAU-only group had a $6.2 \mathrm{mmHg}$ reduction from the previous study. ${ }^{12}$ In this simulation model, we used DTx+TAU and TAU-only effect distributions derived from the HERB-DH1 trial data (Supplemental Figure). Since DTx adherence could decrease with time, we set the model such that $25 \%$ of the remaining users in the DTx+TAU group attrited using the DTx every 6 months.

\section{Mortality and complications}

We obtained the annual natural death rates from the Japan Vital Statistics for $2022 .{ }^{16}$ the annual mortality and occurrence rates of each complication are summarized in Table 1. We set both acute and post-state (chronic) mortality rates for each complication. ${ }^{17-21}$

The occurrence rates of each complication were adjusted according to the BP categories (Supplemental Table). ${ }^{17}$ Additionally, the annual incidence rates of CAD and stroke were 
medRxiv preprint doi: https://doi.org/10.1101/2022.03.02.22271583; this version posted March 4, 2022. The copyright holder for this preprint

(which was not certified by peer review) is the author/funder, who has granted medRxiv a license to display the preprint in perpetuity. It is made available under a CC-BY 4.0 International license .

calibrated referring to the previously reported lifetime risks. ${ }^{22,}{ }^{23}$ In addition, the annual incidence rate of HF was calibrated by a patient's age (hazard ratios [HRs] of 2.5, 5.0, and 10 for the 60s, 70s, and $\geq 80 \mathrm{~s}) .{ }^{24}$ Categories of normal BP, elevated BP, grade I HT, and grade II HT were defined as home SBPs of $<125,125-134,135-144$, and $\geq 145 \mathrm{mmHg}$, respectively. ${ }^{7}$ Since the cycle length of the model was 1 month, we converted the annual rates to the monthly rates to input the model.

Costs

A list of the cost data is presented in Table 1. We performed an economic estimation from Japan's public healthcare payer perspective, under which only medical costs were considered. The costs consist of treatment and hospitalization expenses, but not transportation fees or family care service costs. We set the monthly cost of HERB DTx at $¥ 10,000$ (\$86.96 US: \$1 US $=¥ 115$ as of January 2022), including the app purchases and subscription fees. The cost of each complication (CAD, stroke, HF, and AFib) was also derived from previous studies. ${ }^{25-28}$ We set annual cost reduction by $2 \%$ according to the Japanese guideline for cost-effectiveness analyses. $^{29}$

\section{Health-related quality of life and utilities}

We derived the utility values of CAD, stroke, HF, and AFib from published studies based on the European Quality of Life-5 Dimensions Questionnaire (Table 1). ${ }^{28,30,31}$ We calculated the QALY by multiplying the time duration in a specific health state by the utility value associated with the state. Both cost and outcome were discounted at a $2 \%$ discount rate. ${ }^{29}$

\section{Main analysis}


medRxiv preprint doi: https://doi.org/10.1101/2022.03.02.22271583; this version posted March 4, 2022. The copyright holder for this preprint

(which was not certified by peer review) is the author/funder, who has granted medRxiv a license to display the preprint in perpetuity. It is made available under a CC-BY 4.0 International license .

We calculated the ICER between DTx+TAU and TAU-only strategies over the lifetime horizon using the estimated model parameters and cost and effectiveness assumptions.

\section{Sensitivity and scenario analyses}

We tested the impact of the uncertainties around the model parameters on the overall costeffectiveness results using one-way deterministic and probabilistic sensitivity analyses. First, we performed one-way deterministic sensitivity analyses by changing the treatment effect, cost, and utility parameters over each range between low and high values (Table 1 and Supplemental Table). Then, we conducted probabilistic sensitivity analyses to evaluate the sensitivity of the results to simultaneous variable changes using a set of 2 million $(2,000$ iterations $\times 1,000$ individuals) simulated results with specific probability distributions of the input parameters. We assumed a Weibull distribution for age, log-normal distribution for initial SBP input, normal distributions for HRs of each complication by BP grades, mortality rates, and health utilities, beta distributions for clinical event incidence rates, and gamma distributions for costs. In addition, we drew the probability of the cost-effectiveness acceptability curve to evaluate the cost-effectiveness probability at a willingness-to-pay threshold of $¥ 5$ million $(\$ 43,478)$. Additionally, we conducted two scenario analyses as follows: \#1) simulating different time horizons of 20, 30, and 40 years; and \#2) setting an alternative DTx app attrition rate of $10 \%$ every 6 months. All model analyses were conducted using TreeAge Pro HealthCare version 2022 R1.0 (TreeAge Software, LLC, MA, USA). 
medRxiv preprint doi: https://doi.org/10.1101/2022.03.02.22271583; this version posted March 4, 2022. The copyright holder for this preprint

(which was not certified by peer review) is the author/funder, who has granted medRxiv a license to display the preprint in perpetuity.

\section{Results}

Main analysis

The model predicted that the DTx+TAU strategy produced 18.778 QALY and was associated with $¥ 3,924,075(\$ 34,122)$ expected costs compared to 18.686 QALY and $¥ 3,813,358$ $(\$ 33,160)$ generated by TAU-only treatment over a lifetime horizon. The introduction of DTx would increase costs by $¥ 110,017$ (\$963) and prolong QALY by 0.092 . The ICER of DTx+TAU against TAU would be $¥ 110,017 / 0.092$ QALY $=¥ 1,199,880(\$ 10,434) / Q A L Y$ gained, which were well below the hypothetical threshold value in Japan, or ¥5 million/QALY gained (Table 2).

\section{Sensitivity analyses}

We conducted one-way deterministic and probabilistic sensitivity analyses. The results of the one-way deterministic sensitivity analyses with the tornado diagram are shown in Figure 2. The monthly cost of DTx, which ranged from $¥ 5,000$ (\$43.48)/month to $¥ 20,000$ (\$173.91)/month, had the largest impact on the ICER value, followed by the DTx attrition and discount rates. According to the one-way threshold analysis for the monthly DTx cost, the DTx+TAU arm became the dominant strategy when the cost was below $¥ 5,163$ (\$44.90) per month. Even the highest ICER value observed in this diagram was still below the threshold value, or ¥5 million/QALY gained.

The results of the probabilistic sensitivity analysis are shown with incremental costeffectiveness scatter plots (Figure 3) and a cost-effectiveness acceptability curve (Figure 4). According to these figures, the probability of dominance (DTx less costly and more effective) and cost-effectiveness (DTx more costly and more effective, the ICER was less than $¥ 5$ million /QALY gained) were $81.3 \%$ and $6.5 \%$, respectively. 
medRxiv preprint doi: https://doi.org/10.1101/2022.03.02.22271583; this version posted March 4, 2022. The copyright holder for this preprint (which was not certified by peer review) is the author/funder, who has granted medRxiv a license to display the preprint in perpetuity. It is made available under a CC-BY 4.0 International license .

\section{Scenario analyses}

In scenario \#1, by changing the simulation duration, the ICERs for DTx+TAU treatment were inversely proportional to the extent of the time horizon (Table 2). In scenario \#2, using an alternative DTx attrition rate of $10 \%$ every 6 months, ICER was reached in $¥ 4,213,612$ $(\$ 37,655) / \mathrm{QALY}$. 
medRxiv preprint doi: https://doi.org/10.1101/2022.03.02.22271583; this version posted March 4, 2022. The copyright holder for this preprint

(which was not certified by peer review) is the author/funder, who has granted medRxiv a license to display the preprint in perpetuity. It is made available under a CC-BY 4.0 International license.

\section{Discussion}

In this study, we assessed the cost-effectiveness of prescription DTx for essential hypertension, in addition to TAU, compared to the TAU-only strategy. We found that the ICER of the DTx +TAU strategy was $¥ 1,199,880(\$ 10,434) / Q A L Y$ against the TAU-only strategy in the lifetime horizon, which was well below the threshold value, or ¥5 million /QALY. Moreover, the probability of the cost being below the threshold value was $87.8 \%$ in the probabilistic sensitivity analysis. This model analysis demonstrated that DTx+TAU is cost-effective for patients with hypertension.

There are several conclusions that can be drawn from this study. First, this is the first study to evaluate the cost-effectiveness of DTx for patients with hypertension using the results of an RCT. Nordyke et al. reported the good cost-effectiveness of DTx for hypertension with person-to-person health coaching from retrospective study data over a 3 year time horizon. ${ }^{32}$, 33 Other than hypertension, DTx for opioid use disorder and that for low back pain also revealed cost-effectiveness in a relatively short time horizon (12 weeks to 3 years) without considering mortality rates. ${ }^{13-15}$ Although the DTx usage half-time was around 15 months in this model, the benefit of the BP-lowering effect persisted for long life above 3 years, resulting in prevention of the trajectory of cardiovascular disease from hypertension, left ventricular hypertrophy, atherosclerotic CVD events, and finally to HF and CVD deaths. Therefore, a long-term cost-effectiveness analysis would be valuable when considering the practical effects of DTx for chronic diseases such as hypertension.

The monthly cost of DTx for hypertension had the greatest impact on ICERs in the oneway deterministic sensitivity analysis. Lewkowicz et al. pointed out the same conclusion by evaluating the cost-effectiveness of DTx for low back pain. ${ }^{15}$ At a DTx cost of $¥ 5,000 /$ month, DTx dominated conventional therapy, or being less costly and more effective option. Even when we set the cost at $¥ 20,000 /$ month, the ICER was approximately $¥ 3.5$ million/QALY, still 
medRxiv preprint doi: https://doi.org/10.1101/2022.03.02.22271583; this version posted March 4, 2022. The copyright holder for this preprint (which was not certified by peer review) is the author/funder, who has granted medRxiv a license to display the preprint in perpetuity. It is made available under a CC-BY 4.0 International license .

under the threshold value of $¥ 5$ million/QALY (Figure 2). Recently, sacubitril/valsartan (angiotensin receptor-neprilysin inhibitor), a novel antihypertensive drug, was approved for hypertension management in $\mathrm{Japan}^{34}$, with a medication cost of $¥ 6,057$ (\$53) to $¥ 12,114$ (\$105) /month. Thus, the DTx cost we set around $¥ 10,000$ /month as the default might be a reasonable value according to the current simulation model.

The attrition rate of the DTx program is a crucial factor for cost-effectiveness. A smartphone mHealth app usage rate was attenuating over time, reported approximately $40 \%$ of attrition occurred in 6 months to 1 year. ${ }^{35}$ Previous DTx studies for cost-effectiveness analyses also used similar attrition rates. ${ }^{15,32}$ Thus, it could be reasonable to set the attrition rate of $25 \%$ every 6 months in this model, which half time was around 15 months since the initiation of DTx. In another scenario, when we changed the rate to $10 \%$ (lower than the predefined 25\%), the half time exceeded approximately 40 months, and the ICER was increased to approximately $¥ 4.2$ million/QALY, which was close to the threshold value (Figure 2). Lewkowicz et al. previously reported that lowering the DTx app attrition rate was essential for cost-effectiveness in a relatively short-term (3 years) horizon. ${ }^{15}$ Although the model inputs and target disease were different, it might be possible that high attrition rates along with DTx actual usage duration could substantially impact DTx cost-effectiveness. Achieving good cost-effectiveness in DTx, we might face sensitive handling to balance the appropriate DTx app usage duration with DTx costs and expected attrition rate.

The degree of the gained ICER in DTx hypertension management surely depends on the degree of BP reduction by quality of the DTx app algorithm, the impact of BP reduction, and the cost of cardiovascular events in each country. A significant difference in home BP reduction (-4.3 mmHg of morning home SBP) was clearly found between the DTx+TAU and TAU-only groups from the previous phase III clinical trial. It is noteworthy that this TAU-only group followed the ideal guideline-driven management of hypertension, which used home BP 
medRxiv preprint doi: https://doi.org/10.1101/2022.03.02.22271583; this version posted March 4, 2022. The copyright holder for this preprint

(which was not certified by peer review) is the author/funder, who has granted medRxiv a license to display the preprint in perpetuity. It is made available under a CC-BY 4.0 International license.

monitoring. ${ }^{7}$ Compared with office BP, home BP is more closely associated with cardiovascular event risk. ${ }^{36,37}$ In addition, in Asian countries, the benefit of BP lowering is greater than that of Westerners, especially for stroke. ${ }^{38}$ The comparison of cost-effectiveness studies using different DTx apps in different contigs is also needed in the future.

The strength of this study is that, to our knowledge, this is the first study to evaluate the cost-effectiveness of DTx for patients with hypertension using the results from an RCT. Furthermore, we demonstrated that DTx+TAU is cost-effective for patients with hypertension. This study has some limitations. First, we simulated middle-aged, digital-friendly grade I or II hypertensive patients without taking antihypertensive medication from the previous RCT results. Thus, caution should be taken when applying our results to a broader population. Second, we modelled the DTx effect as permanent, although the effect estimates were derived from the 6-months duration of the HERB-DH1 trial results. Although we set the BP reduction effects even for the TAU-only strategy, this could lower the mortality and complication occurrence rates in the DTx+TAU strategy. Third, we did not estimate additive effects of having multiple comorbidities in this model, which could impact lifetime ICER. Fourth, we could not strictly assess the DTx cost-effectiveness in addition to antihypertensive medications since the model patients derived from previous trials were all antihypertensive drug-naïve. Finally, we did not consider re-using DTx after finishing the initial DTx usage according to the attrition rate, which could account for additional costs for the DTx strategy.

\section{Perspective}

In summary, DTx+TAU demonstrated good cost-effectiveness in hypertensive patients compared to the TAU-only strategy. DTx cost and its attrition rate largely influenced costeffectiveness, and we need to explore the balance among the DTx application cost, app attrition rate, and effectiveness for target hypertensive patients in clinical practice. DTx is generally 
medRxiv preprint doi: https://doi.org/10.1101/2022.03.02.22271583; this version posted March 4, 2022. The copyright holder for this preprint

(which was not certified by peer review) is the author/funder, who has granted medRxiv a license to display the preprint in perpetuity. It is made available under a CC-BY 4.0 International license .

reimbursed by Japan's national universal health insurance system. Thus, it is becoming increasingly essential to evaluate the cost-effectiveness of DTx, as in this study, to consider the appropriate value-based reimbursement pricing.

\section{Acknowledgements}

We would like to express our gratitude to all participants regarding this study.

\section{Source of funding}

The HERB-DH1 RCT, the data of which were used in this study, was sponsored by CureApp, Inc. (Tokyo, Japan). In addition, CureApp Inc. has patents and distribution rights for the HERB mobile prescription DTx system.

\section{Disclosures}

Akihiro Nomura, Kazuomi Kario, and Ataru Igarashi received consulting fees from CureApp Inc. Akihiro Nomura was co-founder of the CureApp Institute. Tomoyuki Tanigawa is the chief medical officer of CureApp, Inc. 
medRxiv preprint doi: https://doi.org/10.1101/2022.03.02.22271583; this version posted March 4, 2022. The copyright holder for this preprint (which was not certified by peer review) is the author/funder, who has granted medRxiv a license to display the preprint in perpetuity. It is made available under a CC-BY 4.0 International license.

\section{References}

1. World Health Organization. Hypertension. Aug 25, 2021;(Last accessed: Jan 29, 2022).

2. G. B. D. Risk Factors Collaborators. Global burden of 87 risk factors in 204 countries and territories, 1990-2019: a systematic analysis for the Global Burden of Disease Study 2019. Lancet. 2020;396:1223-1249.

3. Ministry of Health Labour and Welfare. Japan National Health and Nutrition Survey 2017. (Last accessed: Dec 1,2021).

4. Fujiyoshi A, Ohkubo T, Miura K, Murakami Y, Nagasawa SY, Okamura T, Ueshima $\mathrm{H}$ and Observational Cohorts in Japan Research G. Blood pressure categories and long-term risk of cardiovascular disease according to age group in Japanese men and women. Hypertens Res. 2012;35:947-53.

5. Matsumoto K, Hanaoka S, Wu Y and Hasegawa T. Comprehensive Cost of Illness of Three Major Diseases in Japan. J Stroke Cerebrovasc Dis. 2017;26:1934-1940.

6. Special Committee on Planning of Next National Health Promotion Campaign Health Sciences Council. Information material on the promotion of Health Japan 21 (Second edition) (July 2012). (Last accessed: Jul 16, 2019).

7. Umemura S, Arima H, Arima S, Asayama K, Dohi Y, Hirooka Y, Horio T, Hoshide S, Ikeda S, Ishimitsu T, Ito M, Ito S, Iwashima Y, Kai H, Kamide K, Kanno Y, Kashihara N, Kawano Y, Kikuchi T, Kitamura K, Kitazono T, Kohara K, Kudo M, Kumagai H, Matsumura K, Matsuura H, Miura K, Mukoyama M, Nakamura S, Ohkubo T, Ohya Y, Okura T, Rakugi H, Saitoh S, Shibata H, Shimosawa T, Suzuki H, Takahashi S, Tamura K, Tomiyama H, Tsuchihashi T, Ueda S, Uehara Y, Urata H and Hirawa N. The Japanese Society of Hypertension Guidelines for the Management of Hypertension (JSH 2019). Hypertens Res. 2019;42:1235-1481.

8. Wang J, Qiu B, Du JL, Deng SB, Liu YJ and She Q. The effects of a low-salt diet on the efficacy of different antihypertensive drug regimens. J Clin Pharmacol. 2015;55:1362-8. 9. Weir MR, Chrysant SG, McCarron DA, Canossa-Terris M, Cohen JD, Gunter PA, Lewin AJ, Mennella RF, Kirkegaard LW, Hamilton JH, Weinberger MH and Weder AB. Influence of race and dietary salt on the antihypertensive efficacy of an angiotensinconverting enzyme inhibitor or a calcium channel antagonist in salt-sensitive hypertensives. Hypertension. 1998;31:1088-96. 
medRxiv preprint doi: https://doi.org/10.1101/2022.03.02.22271583; this version posted March 4, 2022. The copyright holder for this preprint

10. Nishigaki N, Shimasaki Y, Yoshida T and Hasebe N. Physician and patient perspectives on hypertension management and factors associated with lifestyle modifications in Japan: results from an online survey. Hypertens Res. 2020;43:450-462.

11. Kario K, Nomura A, Harada N, Tanigawa T, So R, Nakagawa K, Suzuki S, Okura A, Hida E and Satake K. A multicenter clinical trial to assess the efficacy of the digital therapeutics for essential hypertension: Rationale and design of the HERB-DH1 trial. J Clin Hypertens (Greenwich). 2020;22:1713-1722.

12. Kario K, Nomura A, Harada N, Okura A, Nakagawa K, Tanigawa T and Hida E. Efficacy of a digital therapeutics system in the management of essential hypertension: the HERB-DH1 pivotal trial. Eur Heart J. 2021;42:4111-4122.

13. Wang W, Gellings Lowe N, Jalali A and Murphy SM. Economic modeling of reSET$\mathrm{O}$, a prescription digital therapeutic for patients with opioid use disorder. J Med Econ. 2021;24:61-68.

14. Velez FF and Malone DC. Cost-Effectiveness Analysis of a Prescription Digital Therapeutic for the Treatment of Opioid Use Disorder. J Mark Access Health Policy. 2021;9:1966187.

15. Lewkowicz D, Wohlbrandt AM and Bottinger E. Digital Therapeutic Care Apps With Decision-Support Interventions for People With Low Back Pain in Germany: CostEffectiveness Analysis. JMIR Mhealth Uhealth. 2022;10:e35042.

16. Ministry of Internal Affiairs and Communications Statistics Bureau. Japan Statistical Yearbook 2022 (Chapter 2-22 Life Table ). (Last accessed: Feb 11, 2022).

17. Kaneko H, Yano Y, Itoh H, Morita K, Kiriyama H, Kamon T, Fujiu K, Michihata N, Jo T, Takeda N, Morita H, Node K, Carey RM, Lima JAC, Oparil S, Yasunaga H and Komuro I. Association of Blood Pressure Classification Using the 2017 American College of Cardiology/American Heart Association Blood Pressure Guideline With Risk of Heart Failure and Atrial Fibrillation. Circulation. 2021;143:2244-2253.

18. Komiyama K, Nakamura M, Tanabe K, Niikura H, Fujimoto H, Oikawa K, Daida H, Yamamoto T, Nagao K, Takayama M and Tokyo CCUNSC. In-hospital mortality analysis of Japanese patients with acute coronary syndrome using the Tokyo CCU Network database: Applicability of the GRACE risk score. J Cardiol. 2018;71:251-258.

19. Goto S, Ikeda Y, Shimada K, Uchiyama S, Origasa H, Kobayashi H and Investigators JT. One-year cardiovascular event rates in Japanese outpatients with myocardial infarction, stroke, and atrial fibrillation. -Results From the Japan Thrombosis Registry for Atrial Fibrillation, Coronary, or Cerebrovascular Events (J-TRACE). Circ J. 2011;75:2598-604. 
medRxiv preprint doi: https://doi.org/10.1101/2022.03.02.22271583; this version posted March 4, 2022. The copyright holder for this preprint (which was not certified by peer review) is the author/funder, who has granted medRxiv a license to display the preprint in perpetuity. It is made available under a CC-BY 4.0 International license .

20. $\quad$ Shiraishi Y, Kohsaka S, Sato N, Takano T, Kitai T, Yoshikawa T and Matsue Y. 9Year Trend in the Management of Acute Heart Failure in Japan: A Report From the National Consortium of Acute Heart Failure Registries. J Am Heart Assoc. 2018;7:e008687.

21. Tsuji K, Sakata Y, Nochioka K, Miura M, Yamauchi T, Onose T, Abe R, Oikawa T, Kasahara S, Sato M, Shiroto T, Takahashi J, Miyata S, Shimokawa H and Investigators C-. Characterization of heart failure patients with mid-range left ventricular ejection fraction-a report from the CHART-2 Study. Eur J Heart Fail. 2017;19:1258-1269.

22. Turin TC, Kokubo Y, Murakami Y, Higashiyama A, Rumana N, Watanabe M and Okamura T. Lifetime risk of acute myocardial infarction in Japan. Circ Cardiovasc Qual Outcomes. 2010;3:701-3.

23. Turin TC, Okamura T, Afzal AR, Rumana N, Watanabe M, Higashiyama A, Nakao Y, Nakai M, Takegami M, Nishimura K, Kokubo Y, Okayama A and Miyamoto Y. Hypertension and lifetime risk of stroke. J Hypertens. 2016;34:116-22.

24. Fujimoto W, Toh R, Takegami M, Hayashi T, Kuroda K, Hatani Y, Yamashita S, Imanishi J, Iwasaki M, Inoue T, Okamoto H, Okuda M, Konishi A, Shinohara M, Murata S, Ogata S, Nishimura K and Hirata KI. Estimating Incidence of Acute Heart Failure Syndromes in Japan- An Analysis From the KUNIUMI Registry. Circ J. 2021;85:1860-1868. 25. Kamae I, Hashimoto Y, Koretsune Y, Tanahashi N, Murata T, Phatak H, Liu LZ, Tang AC, Feng Wang P and Okumura K. Cost-effectiveness Analysis of Apixaban against Warfarin for Stroke Prevention in Patients with Nonvalvular Atrial Fibrillation in Japan. Clin Ther. 2015;37:2837-51.

26. Mizuno A, Iguchi H, Sawada Y, Hurley M, Nomura H, Hayashi K, Tokuda Y, Watanabe S and Yoshikawa A. The impact of carperitide usage on the cost of hospitalization and outcome in patients with acute heart failure: High value care vs. low value care campaign in Japan. Int J Cardiol. 2017;241:243-248.

27. Kamae I, Kitamura A, Sakurai M, Yamamoto M, Inoue S, Shibahara H and Kobayashi M. Economic burden of arterial fibrillation in Japan (abstract). Value Health. 2018;21:S70.

28. Kodera S, Morita H, Kiyosue A, Ando J and Komuro I. Cost-Effectiveness of Percutaneous Coronary Intervention Compared With Medical Therapy for Ischemic Heart Disease in Japan. Circ J. 2019;83:1498-1505.

29. Shiroiwa T, Fukuda T, Ikeda S, Takura T and Moriwaki K. Development of an Official Guideline for the Economic Evaluation of Drugs/Medical Devices in Japan. Value Health. 2017;20:372-378. 
medRxiv preprint doi: https://doi.org/10.1101/2022.03.02.22271583; this version posted March 4, 2022. The copyright holder for this preprint (which was not certified by peer review) is the author/funder, who has granted medRxiv a license to display the preprint in perpetuity. It is made available under a CC-BY 4.0 International license .

30. Hattori N, Hirayama T and Katayama Y. Medical care for chronic-phase stroke in Japan. Neurol Med Chir (Tokyo). 2012;52:175-80.

31. Clarke P, Gray A and Holman R. Estimating utility values for health states of type 2 diabetic patients using the EQ-5D (UKPDS 62). Med Decis Making. 2002;22:340-9.

32. Nordyke RJ, Appelbaum K and Berman MA. Estimating the Impact of Novel Digital Therapeutics in Type 2 Diabetes and Hypertension: Health Economic Analysis. J Med Internet Res. 2019;21:e15814.

33. Guthrie NL, Berman MA, Edwards KL, Appelbaum KJ, Dey S, Carpenter J, Eisenberg DM and Katz DL. Achieving Rapid Blood Pressure Control With Digital Therapeutics: Retrospective Cohort and Machine Learning Study. JMIR Cardio. 2019;3:e13030.

34. Rakugi H, Kario K, Yamaguchi M, Sasajima T, Gotou H and Zhang J. Efficacy of sacubitril/valsartan versus olmesartan in Japanese patients with essential hypertension: a randomized, double-blind, multicenter study. Hypertens Res. 2022.

35. Meyerowitz-Katz G, Ravi S, Arnolda L, Feng X, Maberly G and Astell-Burt T. Rates of Attrition and Dropout in App-Based Interventions for Chronic Disease: Systematic Review and Meta-Analysis. J Med Internet Res. 2020;22:e20283.

36. Kario K, Shimbo D, Hoshide S, Wang JG, Asayama K, Ohkubo T, Imai Y, McManus RJ, Kollias A, Niiranen TJ, Parati G, Williams B, Weber MA, Vongpatanasin W, Muntner P and Stergiou GS. Emergence of Home Blood Pressure-Guided Management of Hypertension Based on Global Evidence. Hypertension. 2019:HYPERTENSIONAHA11912630.

37. Kario K. State-of-the-Art review: Home blood pressure monitoring: current status and new developments. Am J Hypertens. 2021.

38. Kario K, Park S, Chia YC, Sukonthasarn A, Turana Y, Shin J, Chen CH, Buranakitjaroen P, Divinagracia R, Nailes J, Hoshide S, Siddique S, Sison J, Soenarta AA, Sogunuru GP, Tay JC, Teo BW, Zhang YQ, Van Minh H, Tomitani N, Kabutoya T, Verma N, Wang TD and Wang JG. 2020 Consensus summary on the management of hypertension in Asia from the HOPE Asia Network. J Clin Hypertens (Greenwich). 2020;22:351-362. 
medRxiv preprint doi: https://doi.org/10.1101/2022.03.02.22271583; this version posted March 4, 2022. The copyright holder for this preprint

(which was not certified by peer review) is the author/funder, who has granted medRxiv a license to display the preprint in perpetuity. It is made available under a CC-BY 4.0 International license .

\section{Figure legends}

Figure 1. Structure of the simulation model.

A) Decision tree. B) Structure of Markov model. C) Structure of Stay (no acute complications) module. D) Structure of acute complications module.

Figure 2. One-way sensitivity analysis results.

Figure 3. Cost-effectiveness plot.

Figure 4. Cost-effectiveness acceptability curve in DTx+TAU and TAU-only group. 


\section{Tables}

Table 1. Model inputs.

\begin{tabular}{|c|c|c|c|c|}
\hline Data & Input & Low $^{*}$ & High $^{*}$ & Source \\
\hline Age & 52.3 years & - & - & Kario, 2021. \\
\hline Baseline SBP & $148 \mathrm{mmHg}$ & - & - & Kario, 2021. \\
\hline Annual BP increase & $0.5 \mathrm{mmHg}$ & 0.39 & 0.65 & Umemura, 2019 \\
\hline \multicolumn{5}{|l|}{ Annual mortality rates by complications } \\
\hline \multicolumn{5}{|l|}{ Coronary artery disease } \\
\hline First 1 month after event onset & $5.0 \% /$ month & 0 & 5.0 & Komiyama, 2018. \\
\hline$>1$ month (post-CAD) & $0.98 \%$ & 0.93 & 1.74 & Goto, 2011. \\
\hline \multicolumn{5}{|l|}{ Stroke } \\
\hline First 1 month after event onset & $12.9 \% /$ month & 9.7 & 16.1 & Takashima, 2017. \\
\hline$>1$ month (post-Stroke) & $1.29 \%$ & - & - & Goto, 2011. \\
\hline \multicolumn{5}{|l|}{ Heart failure } \\
\hline First 12 months after event onset & $11.5 \%$ & 10.1 & 13.0 & Shiraishi, 2018. \\
\hline$>13$ months (post-HF) & $2.5 \%$ & - & - & Tsuji, 2017. \\
\hline \multicolumn{5}{|l|}{ Atrial fibrillation } \\
\hline First 12 months after event onset & $1.83 \%$ & 1.28 & 2.56 & Goto, 2011. \\
\hline$>13$ months (post-AFib) & \multicolumn{3}{|c|}{ Same as the natural mortality rate } & - \\
\hline \multicolumn{5}{|c|}{ Annual incidence rates of each complication among hypertension patients } \\
\hline Coronary artery disease & $0.460 \%$ & 0.345 & 0.575 & Kaneko, 2021. Turin, 2010. \\
\hline Stroke & $1.592 \%$ & 1.194 & 1.990 & Kaneko, 2021. Turin, 2016. \\
\hline Heart failure & $0.889 \%$ & - & - & Kaneko, 2021. Fujimoto 2021. \\
\hline Atrial fibrillation & $0.232 \%$ & - & - & Kaneko, 2021. \\
\hline \multicolumn{5}{|l|}{ Annual costs } \\
\hline DTx for hypertension & $\begin{array}{c}¥ 120,000 \\
(\$ 1,043)\end{array}$ & 60,000 & 240,000 & Assumption \\
\hline \multicolumn{5}{|c|}{ Acute phase (First 12 months after event onset) } \\
\hline Coronary artery disease & $\begin{array}{c}¥ 2,156,290 \\
(\$ 18,750)\end{array}$ & $1,617,218$ & $2,695,362$ & Kamae, 2015. \\
\hline Stroke & $\begin{array}{c}¥ 1,440,107 \\
(\$ 12,523)\end{array}$ & $1,080,080$ & $1,800,134$ & Kamae, 2015. \\
\hline Heart failure & $\begin{array}{l}¥ 770,428 \\
(\$ 6,699)\end{array}$ & 577,821 & 963,035 & Mizuno, 2017. \\
\hline Atrial fibrillation & $\begin{array}{c}¥ 120,000 \\
(\$ 1,043)\end{array}$ & 90,000 & 150,000 & Kamae, 2018. \\
\hline \multicolumn{5}{|l|}{ Post-complication phase (>12 months) } \\
\hline Coronary artery disease & $\begin{array}{c}¥ 495,600 \\
(\$ 4,310)\end{array}$ & 459,996 & 570,000 & Kodera, 2019 \\
\hline Stroke & $\begin{array}{c}¥ 318,387 \\
(\$ 2,769)\end{array}$ & 262,992 & 372,996 & Kodera, 2019 \\
\hline Heart failure & $\begin{array}{c}¥ 770,428 \\
(\$ 6,699)\end{array}$ & 577,821 & 963,035 & Mizuno, 2017. \\
\hline Atrial fibrillation & $\begin{array}{c}¥ 120,000 \\
(\$ 1,043)\end{array}$ & 90,000 & 150,000 & Kamae, 2018. \\
\hline \multicolumn{5}{|l|}{ Health utilities } \\
\hline Normal & 0.950 & 0.760 & 1.000 & - \\
\hline Coronary artery disease (increment) & -0.180 & -0.135 & -0.225 & Kodera, 2019. \\
\hline Stroke (increment) & -0.157 & -0.117 & -0.196 & Hattori, 2012. \\
\hline Heart failure (increment) & -0.101 & -0.076 & -0.126 & Clarke 2002. \\
\hline Atrial fibrillation (increment) & -0.000 & - & - & Assumption \\
\hline Death (increment) & -0.950 & - & - & - \\
\hline Discount rates & $2 \%$ & 0 & 4 & Shiroiwa, 2017. \\
\hline
\end{tabular}

* Range for sensitivity analysis. 
medRxiv preprint doi: https://doi.org/10.1101/2022.03.02.22271583; this version posted March 4, 2022. The copyright holder for this preprint (which was not certified by peer review) is the author/funder, who has granted medRxiv a license to display the preprint in perpetuity. It is made available under a CC-BY 4.0 International license.

Abbreviations: AF, atrial fibrillation; $\mathrm{BP}$, blood pressure; $\mathrm{CAD}$, coronary artery disease; $\mathrm{CI}$, confidence interval; HF, heart failure; SBP, systolic blood pressure. 
medRxiv preprint doi: https://doi.org/10.1101/2022.03.02.22271583; this version posted March 4, 2022. The copyright holder for this preprint (which was not certified by peer review) is the author/funder, who has granted medRxiv a license to display the preprint in perpetuity. It is made available under a CC-BY 4.0 International license .

Table 2. Cost-effectiveness of DTx for hypertension.

\begin{tabular}{|c|c|c|c|}
\hline Outcome & DTx+TAU & TAU-only & Changes \\
\hline \multicolumn{4}{|c|}{ Lifetime horizon } \\
\hline Costs & $¥ 3,924075(\$ 34,122)$ & $\begin{array}{c}¥ 3,813,358 \\
(\$ 33,160)\end{array}$ & $¥ 110,717(\$ 963)$ \\
\hline QALYs & 18.778 & 18.686 & 0.092 \\
\hline ICER & \multicolumn{3}{|c|}{$¥ 1,199,880(\$ 10,434) / Q A L Y$} \\
\hline \multicolumn{4}{|c|}{ 40-year time horizon } \\
\hline Costs & $¥ 3,705,428$ & $¥ 3,591,385$ & $¥ 114,043$ \\
\hline QALYs & 18.483 & 18.395 & 0.089 \\
\hline ICER & \multicolumn{3}{|c|}{$¥ 1,284,159$ (\$11,166)/QALY } \\
\hline \multicolumn{4}{|c|}{ 30-year time horizon } \\
\hline Costs & $¥ 2,996,162$ & $¥ 2,869,894$ & $¥ 126,268$ \\
\hline QALYs & 17.195 & 17.124 & 0.071 \\
\hline ICER & \multicolumn{3}{|c|}{ 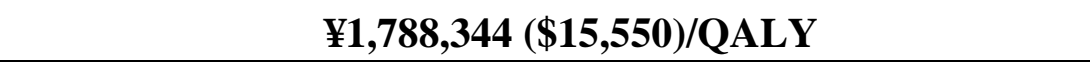 } \\
\hline \multicolumn{4}{|c|}{ 20-year time horizon } \\
\hline Costs & $¥ 1,820,966$ & $¥ 1,664,483$ & $¥ 155,583$ \\
\hline QALYs & 13.939 & 13.903 & 0.037 \\
\hline ICER & \multicolumn{3}{|c|}{$¥ 4,235,677$ (\$36,832)/QALY } \\
\hline
\end{tabular}

Abbreviations: DTx, digital therapeutics; ICER, incremental cost-effectiveness ratio; QALY, quality-adjusted life year; TAU, treatment as usual 
medRxiv preprint doi: https://doi.org/10.1101/2022.03.02.22271583; this version posted March 4, 2022. The copyright holder for this preprint (which was not certified by peer review) is the author/funder, who has granted medRxiv a license to display the preprint in perpetuity.

It is made available under a CC-BY 4.0 International license .

\section{Figures}

\section{Figure 1.}

A

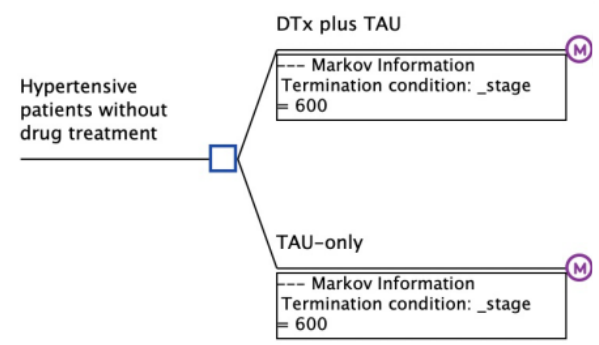

B

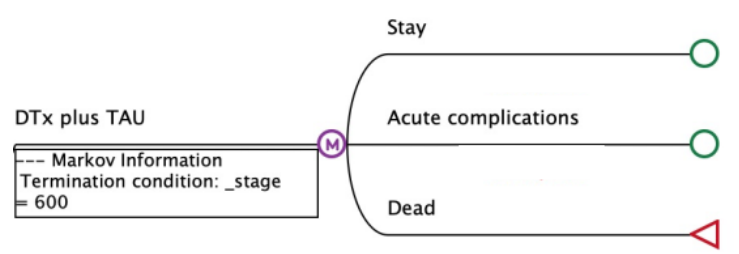

C

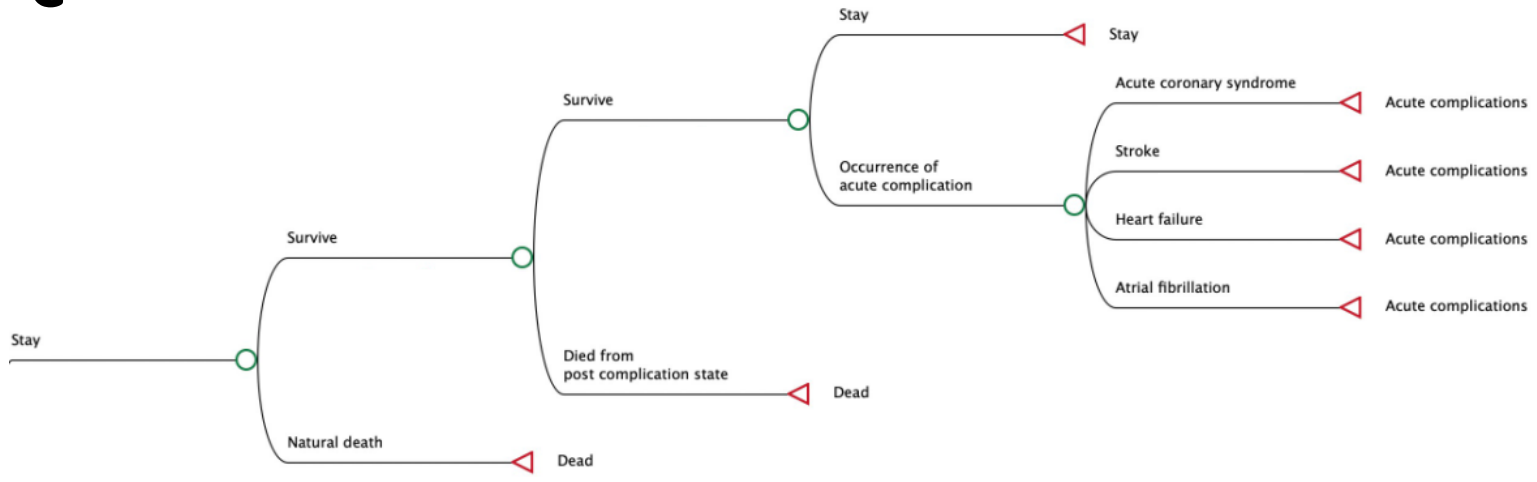

D

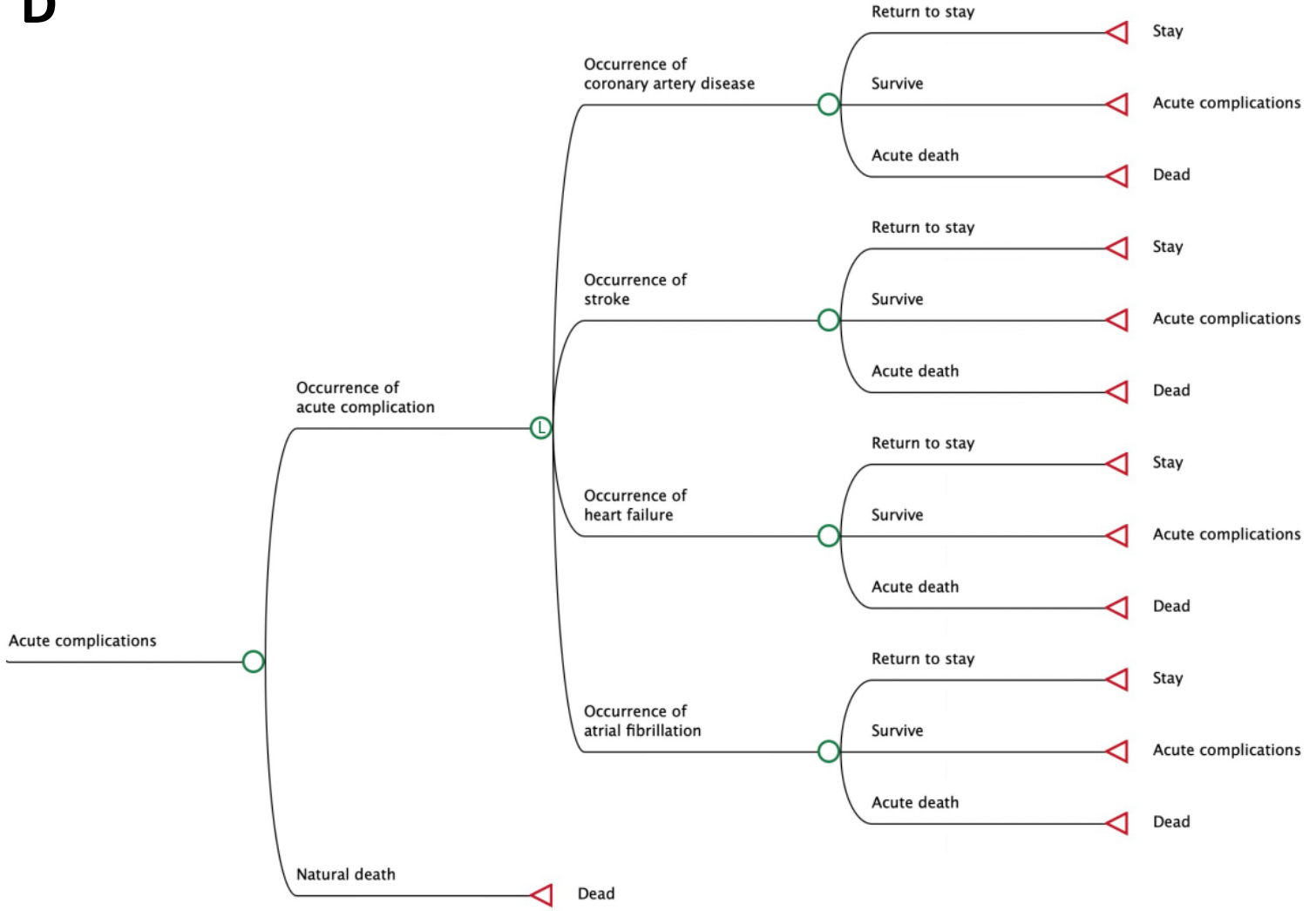


medRxiv preprint doi: https://doi.org/10.1101/2022.03.02.22271583; this version posted March 4, 2022. The copyright holder for this preprint (which was not certified by peer review) is the author/funder, who has granted medRxiv a license to display the preprint in perpetuity. It is made available under a CC-BY 4.0 International license .

\section{Figure 2.}

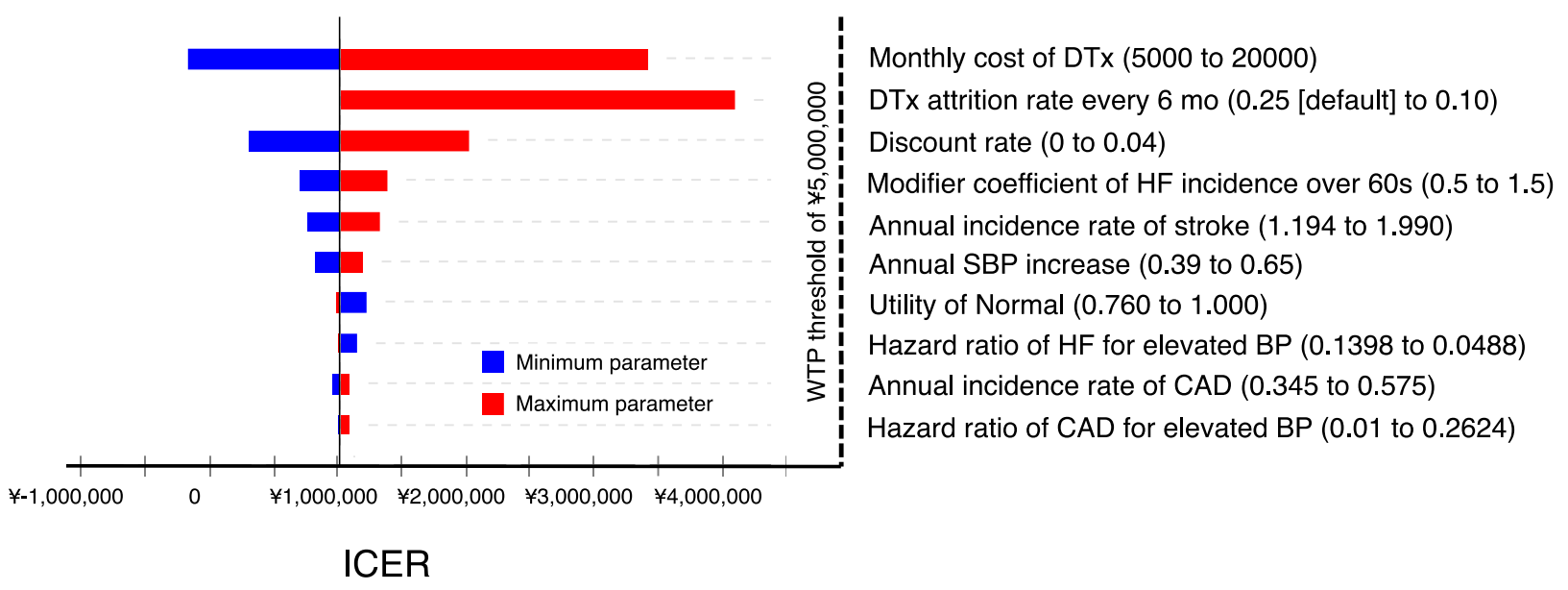


medRxiv preprint doi: https://doi.org/10.1101/2022.03.02.22271583; this version posted March 4, 2022. The copyright holder for this preprint (which was not certified by peer review) is the author/funder, who has granted medRxiv a license to display the preprint in perpetuity.

\section{Figure 3.}

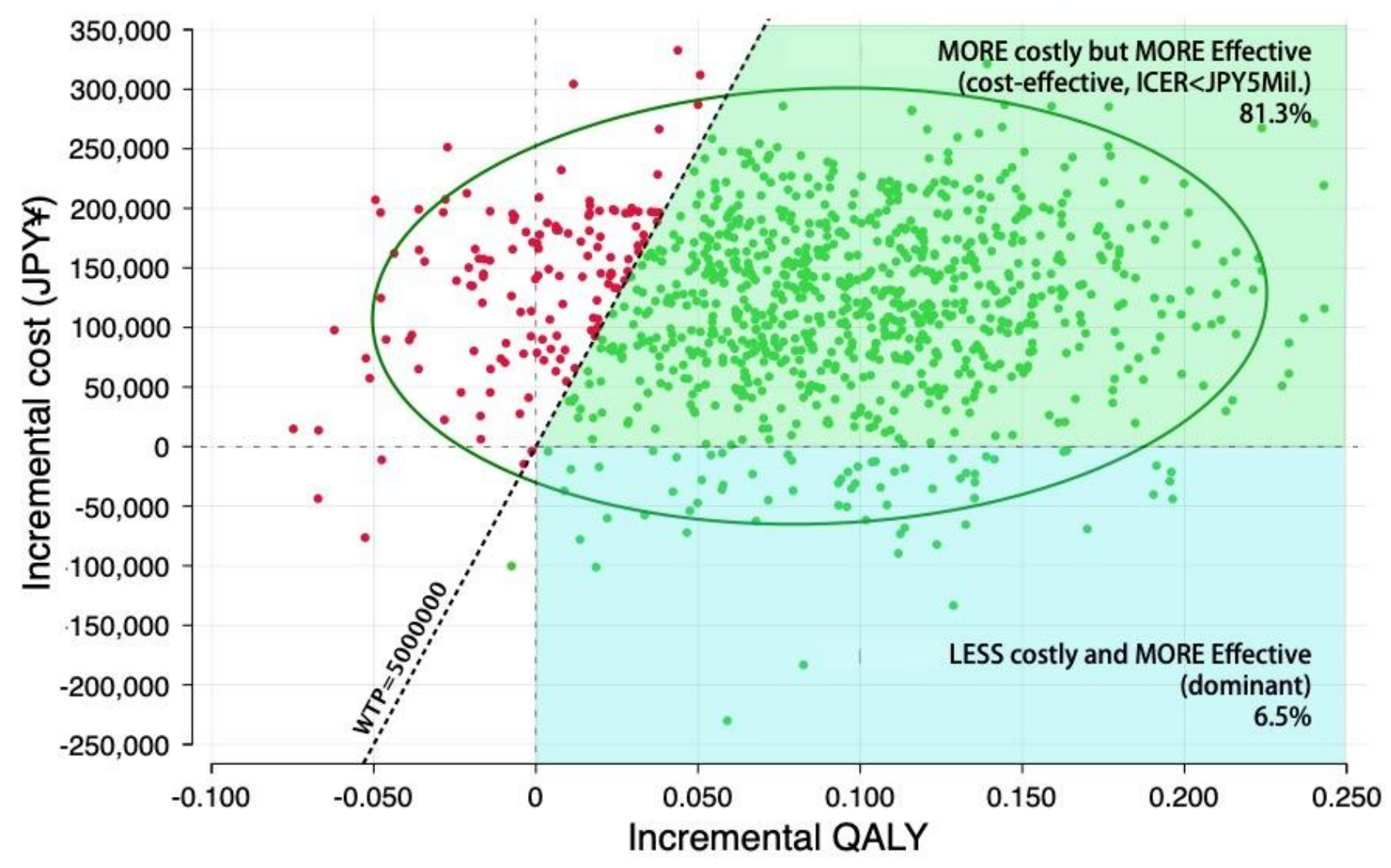


medRxiv preprint doi: https://doi.org/10.1101/2022.03.02.22271583; this version posted March 4, 2022. The copyright holder for this preprint (which was not certified by peer review) is the author/funder, who has granted medRxiv a license to display the preprint in perpetuity. It is made available under a CC-BY 4.0 International license .

\section{Figure 4.}

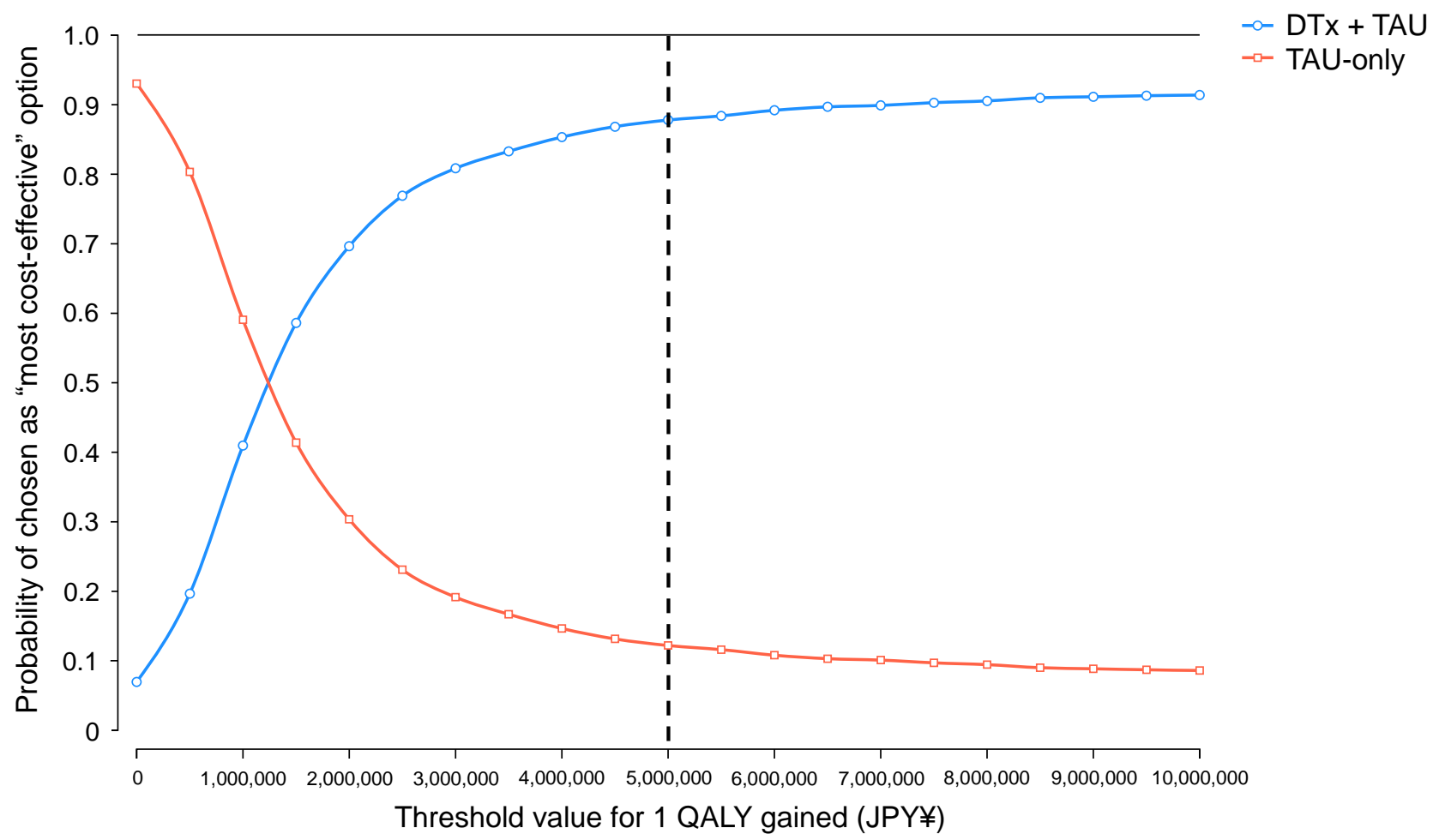

